\title{
Sympozjum liturgiczne Znaczenie i działalność Kongregacji ds. Kultu Bożego i Dyscypliny Sakramentów (Wrocław, 17 maja 2011)
}

17 maja 2011 roku w Auli Papieskiego Wydziału Teologicznego we Wrocławiu odbyło się sympozjum liturgiczne pt. Znaczenie i działalność Kongregacji ds. Kultu Bożego i Dyscypliny Sakramentów. Zorganizowała go Komisja ds. Kultu Bożego i Dyscypliny Sakramentów Konferencji Episkopatu Polski, by wyrazić wdzięczność bp. Stefanowi Cichemu za jego 10-letnią pracę przewodniczącego tej komisji.

Sympozjum rozpoczęło się od Eucharystii w archikatedrze wrocławskiej, której przewodniczył kard. Antonio C. Llovera, prefekt Kongregacji ds. Kultu Bożego i Dyscypliny Sakramentów. On także wygłosił homilię.

Po przywitaniu gości przez rektora Papieskiego Wydziału Teologicznego we Wrocławiu ks. prof. dr. hab. Waldemara Irka jako pierwszy głos zabrał kard. Llovera, który przedstawił referat: Kongregacja ds. Kultu Bożego i Dyscypliny Sakramentów - znaczenie i zadania. W pierwszej części wystąpienia kardynał zaznaczył, że kongregacja czuje się odpowiedzialna za dziedzictwo liturgii i chce mu pozostać wierna. Sam papież Benedykt XVI przedłożył kongregacji konkretne zadania, z których najważniejsze to: przedstawianie właściwego sensu liturgii, ożywianie jej i ukazywanie jako prawdziwego źródła uświęcenia człowieka, przezwyciężenie kryzysu związanego z sekularyzacją wewnątrz samego Kościoła, przedstawianie liturgii jako centrum obecności Boga w życiu człowieka oraz odnowa liturgiczna w duchu konstytucji Sacrosanctum Concilium i Gaudium et spes, które nie zostały jeszcze dobrze zrozumiane w swych najgłębszych pokładach. W tych wszystkich zadaniach potrzebny jest głęboki zmysł Tradycji Kościoła. W konkretnych działaniach ma się to przejawiać w dwóch aspektach: intelektualnym (ukazywanie relacji Bóg-człowiek w pespektywie całej teologii) oraz formacyjnym (przygotowanie prostych materiałów formacyjnych, pomagających kapłanom, osobom konsekrowanym, seminarzystom i wiernym właściwie przeżywać sakramenty święte). Poza tym kard. A. C. Llovera zwrócił uwagę na te zadania kongregacji, które stanowią zwykłe jej działanie, czyli: czuwanie nad życiem liturgicznym Kościoła, usuwanie nadużyć, problemy inkulturacji, tworzenie i zatwierdzanie ksiąg i tekstów liturgicznych oraz troska o muzykę i sztukę liturgiczną.

W drugim wystąpieniu ks. dr Arkadiusz Nocoń, pracownik kongregacji, przedstawił Stan prac nad dokumentami bieżacymi we wspótpracy pomiędzy Konferencją Episkopatu Polski a Kongregacją ds. Kultu Bożego i Dyscypliny Sakramentów. Relacja ta dotyczyła lat 2001-2011. Do najważniejszych dokumentów wydanych przez kongregację w tym czasie należały: trzecie wydanie typiczne Mszału rzymskiego (2002, 2008), Martyrologium Romanum (2001,2004) oraz instrukcje: Liturgiam authenticam (2001) i Redemptionis sacramentum (2004). Z dokumentów tych kongregacja zatwierdziła polskie tłumaczenie Ogólnego Wprowadzenia do Mszału rzymskiego oraz wymienione instrukcje. Ponadto w tym czasie zatwierdzone zostały także tłumaczenia 
wcześniej wydanych ksiąg: Egzorcyzmy i inne modlitwy błagalne i II wydanie typiczne Liturgii godzin. Przyjęto także lekcjonarz dla „Ruchu Światło-Życie”, Obrzędy pogrzebu zwiazzane zkremacją zwłok i wiele nowych tekstów liturgicznych związanych ze wspomnieniami świętych i błogosławionych. Kongregacja watykańska udzieliła też wielu indultów i dyspens (np. Komunia święta na rękę, zgoda na uroczystość św. Stanisława w Krakowie w III Niedzielę Wielkanocną w roku 2011), zatwierdziła kalendarze liturgiczne nowych patronów dla grup społecznych, miast, diecezji i Polski, zatwierdziła wiele bazylik mniejszych oraz wydała zgodę na koronacje obrazów i figur. Inicjatywą samej polskiej komisji były obrzędy konsekracji wdów, jednak nie zostały one zaakceptowane, gdyż nie może się pojawić taka księga, zanim Stolica Apostolska nie opublikuje najpierw jej wydania typicznego.

Trzecim prelegentem był prof. Roberto Fusco (Watykan), który wygłosił referat: Nadanie tytułu bazyliki mniejszej znakiem szczególnej więzi z Kościołem Rzymskim i z osobą Następcy św. Piotra. Przypomniał on najpierw historię nadawania tego tytułu oraz przedstawił zadania wynikające z tego aktu, które zawarte są w dwóch dokumentach: Domus Dei (1968) i Domus Ecclesiae (1989). Tytuł bazyliki mniejszej nadaje się kościołom poza Rzymem od roku 1783. Przez pierwsze 206 lat (do 1989 roku) tytuł ten otrzymało w Polsce 56 kościołów, natomiast przez następne 22 lata - aż 62. W Polsce mamy więc 119 bazylik na ogólną liczbę 1590 w świecie. Najwięcej jest ich w diecezji krakowskiej - 13, choć nie wszystkie z nich posiadają dokumenty ich ustanowienia (chodzi o bazylikę Świętych Apostołów Piotra i Pawła, Świętego Krzyża i katedrę na Wawelu). Przedstawiając te statystyki, profesor zaapelował, by bazyliki te naprawdę reprezentowały wpływ lex orandi na lex vivendi, by stawały się ośrodkami duchowymi, które oddziałują nie tylko architekturą, ale także liturgią i miłością.

Ostatnim mówcą był ks. prof. Helmut Sobeczko (Opole), który przedstawił Działalność Komisji Konferencji Episkopatu Polski ds. Kultu Bożego i Dyscypliny Sakramentów w latach 20012011. Ksiądz profesor przedstawił najpierw krótką historię tej komisji, która rozpoczęła działalność w 1919 roku. Następnie zaprezentował współczesną działalność Komisji, w której pracuje 13 osób: 4 biskupów i 9 konsultorów. Prace komisji idą w dwóch kierunkach: wprowadzenie reformy liturgicznej i nowych ksiąg liturgicznych oraz działalność formacyjna. Komisja ta czuwa m.in. nad wprowadzaniem w życie zarządzeń Stolicy Apostolskiej i Konferencji Episkopatu Polski (której przedstawia sprawozdania), opracowuje sprawy związane z liturgią zarówno pod względem obrzędowym, jak i duszpasterskim, przeprowadza badania związane $z$ duszpasterstwem liturgicznym, kieruje opracowaniem przekładów łacińskich na język polski, czuwa nad przygotowaniem do nich melodii, opracowuje adaptacje tekstów i obrzędów dla potrzeb diecezji, ustala formę typograficzną i oprawę graficzną polskich ksiąg liturgicznych, opracowuje przekłady instrukcji Stolicy Apostolskiej dotyczących liturgii, sama przygotowuje instrukcje krajowe w tym zakresie, opracowuje teksty i melodie do nabożeństw pozaliturgicznych, sprawdza polskie przekłady tekstów liturgicznych, czuwa nad formacją liturgiczną służby liturgicznej, popiera dzieła apostolstwa liturgicznego i biblijnego, udziela wyjaśnień w sprawach liturgicznych i współpracuje z innymi komisjami episkopatu. Od 1994 roku komisja wydaje swój kwartalnik „Anamnesis”, a od 2002 roku prowadzi stronę internetową. Po ostatnim wystąpieniu nastąpiło zamknięcie obrad i zakończenie sympozjum. 